\title{
THE NORTH CYPRUS CONFERENCE SECTOR: ESTABLISHING A COMPETITIVE ADVANTAGE
}

\author{
JULIDE ORAL and JULIE WHITFIELD
}

School of Tourism, Bournemouth University, Poole, Dorset, UK

\begin{abstract}
North Cyprus had recently positioned itself as a conference destination. Given external and internal factors such as political isolation and the over dependency on casino tourism, policy makers have recognized the importance of the conference sector in creating sustainable growth for North Cyprus's tourism-driven economy. Increasingly, Turkish conference organizers are choosing North Cyprus as a destination to host conferences. As such, Turkish conference organizers were questioned via an Internet-based questionnaire to determine attributes considered important within the conference destination selection process. An Importance-Performance Analysis (IPA) was performed; the findings identified that North Cyprus was perceived as a high performer with reference to: ease of accessibility, distance of destination, conference venue and accommodation price, safety and security, climate, hospitality, quality, quantity, and availability of hotel rooms. However, in relation to North Cyprus, a unique application of IPA identified macro- and microdestination attributes that North Cyprus should improve on: transportation within destination, availability of technological resources, the range of conference venues, conference staff training, destination's marketing activities, and quality of local restaurants. The findings provided implications for destination managers in terms of branding, as well as conference venue and accommodation providers in terms of targeting conference organizers more effectively and promoting North Cyprus to conference sector stakeholders.
\end{abstract}

Key words: Turkish Republic of North Cyprus; Conference sector; Importance-Performance Analysis; Business tourism; Casino

\section{Introduction}

Cyprus is located in the Mediterranean Sea, approximately $60 \mathrm{~km}$ South of Turkey, $96 \mathrm{~km}$ West of Syria, and $322 \mathrm{~km}$ from the mainland of Greece (Rustem, 1987). The island exists as a bicommunal republic established in 1960 by Turkish and
Greek Cypriot cofounders. Since 1974 Cyprus has been geographically separated. In the South, Greek Cypriots are the islands majority, with Turkish Cypriots forming the minority to the North (M. Altinay \& Bicak, 1998). In 1983, North Cyprus declared independence as the Turkish Republic of Northern Cyprus (TRNC), although this Republic 
is only recognized by Turkey. In the latter half of the 1980s North Cyprus declared its tourism sector as the principle driver of economic development (M. Altinay \& Hussain, 2005). However, as an internationally isolated island state, which imports a large proportion of the goods and produce consumed by tourism, and with no direct flights, North Cyprus has achieved limited success in the mass tourism market (Alipour \& Kilic, 2005).

In response to this, North Cyprus has recently positioned itself as a conference destination investing in the conference sector with aspirations of making North Cyprus an international conference destination. Increasingly, Turkish conference organizers are choosing North Cyprus as a destination to host conferences. The Turkish conference market offers greater potential than vacation or casino tourism. The modern-day conference sector is one of the fastest growing, and highest yielding sectors within the overall tourism industry (Whitfield, 2009). However, delivering both customer value and satisfaction are crucial elements in maintaining the attractiveness and competitive advantage of the North Cyprus conference sector.

Importance-Performance Analysis (IPA) is an effective method for evaluating a conference destination's competitive position in the marketplace, thus identifying improvement opportunities and guiding strategic planning efforts in seeking to establish a competitive advantage (Deng, 2008; Hawes \& Rao, 1985; Martilla \& James, 1977; Myers, 1999). In terms of North Cyprus, the application of IPA is unique in that it identifies macro- and microdestination attributes. In terms of macrodestination attributes these relate to the destination as a whole, while microdestination attributes relate to the individual agents that constitute the destination (e.g., conference venues, hotels, restaurants). Overall, IPA identifies which product and/or service attributes a conference destination should focus on to enhance customer satisfaction (Matzler, Fuchs, \& Schubert, 2004). Thus, the primary aim of this article is to determine what product and/or service attributes attracts Turkish conference organizers to North Cyprus. Additionally, this article investigates how North Cyprus could maintain and develop itself as a conference destination. Identifying attributes that could be used within any branding/promotional exercise under- taken by North Cyprus. With this in mind, the article concludes by providing policy makers and destination managers, as well as conference venue and accommodation providers, in North Cyprus with recommendations.

\section{The Political, Economic, and Sociocultural Development of North Cyprus}

The historical development of Cyprus is well documented (Arasli, Katircioglu, \& Mehtap-Smadi, 2005; Hitchens, 1997; Ostergren \& Rice, 2004; Yirmibesoglu, 2008). It is not the authors' intention to provide a further in-depth analysis of the political, economic, and sociocultural history of the island, but rather to précis the pertinent temporal events.

In 1974, following decades of political, economic, and sociocultural turmoil, an attempted coup d'etat by Greek Cypriot military against the incumbent government, led to Turkish military intervention. Approximately 160,000 Greek Cypriots fled south, while 50,000 Turkish Cypriots fled north. This resulted in the island being divided into two distinct geographical regions (Sonmez \& Apostolopoulos, 2000). In 1975, North Cyprus declared a Turkish Federative State of Cyprus (Kıbrıs Türk Federe Devleti), which was rejected by the Republic of Cyprus, the United Nations (UN), and the international community. Eight years of failed negotiations followed until 1983, when the North declared its independence as the TRNC (Yirmibesoglu, 2008). This unilateral declaration of independence was again rejected by the Republic of Cyprus, the UN, and the international community; indeed, North Cyprus today is only recognized by Turkey. The North's economy remains highly dependent on foreign aid from Turkey (Alipour \& Kilic, 2005). After continued political negotiation, the border between the North and South opened in April 2003, and in 2004 a referendum took place on an UN-brokered peace settlement. Turkish Cypriots accepted the proposal, while Greek Cypriots rejected it. Consequently, Cyprus became a European Union member as a segregated island, with North Cyprus effectively excluded.

An international trade embargo was initiated against North Cyprus, which is effectively a closed 
state. It is unable to establish any economic and/ or political relations with other nations, other than Turkey, due to its political nonrecognition and imposed embargoes. As a consequence there are no direct flights to the North, with flights being routed via Turkey prior to their final destination at either Geçitkale or Ercan airports, airports only recognized by Turkey. In addition, North Cyprus's seaports of Kyrenia and Famagusta are deemed closed to shipping by the Republic of Cyprus since 1974 (Warner, 1999). As an island state it imports a large proportion of the goods and produce consumed, which it does so via Turkey. Overall, North Cyprus has remained far less developed than the Republic of Cyprus to the South (Webster \& Dallen, 2006). In response to this, tourism was viewed as a basic priority sector for the economic development of North Cyprus (Arasli et al., 2005).

\section{The Tourism Sector of North Cyprus:}

From Vacation to Casino to Conferences

Prior to 1974, North Cyprus undertook the greatest share of tourism development (Butler \& Mao, 1995; Lockhart, 1997), However, since 1974 tourism has been developed extensively in South Cyprus (Andronikou, 1987), while declining with underdevelopment in the North (Clements, 1998). Overall, the failure of the tourism sector in North Cyprus can be attributed to two broad factors; that of external and internal/endogenous (Alipour \& Kilic, 2005). External factors were created through the islands partition, and exacerbated by the South's continual efforts to achieve unification of Cyprus. These factors include the total international embargo on the North, lack of communication between the island's two geographic regions, international sanctions on aviation and trade, nonrecognition by the international community, a military presence, and continual dependency on Turkish financial assistance (Akis, Peristianis, \& Warner, 1996; Dodd, 1995; Lockhart, 1997).

Internal/endogenous factors include institutions responsible for the development of tourism. From a planning and policy perspective, the government, and its respective agencies, is the principle institution responsible for tourism development (Alipour \& Kilic, 2005). For the last 30 years of partition and 20 years of independence, the North's government did not establish a viable economic system comparable with that of the South, but instead focused on establishing a robust agricultural sector serving the predominantly rural population (Ioannides, 1995). Thus, the tourism sectors' evolution has suffered due to these institutional weaknesses (Alipour \& Kilic, 2005; Aron, 2000). Additionally, public transport stock is old and infrastructure problematic. This has been accepted and improvement to the transport infrastructure has begun (Gurbuz, 2009). A lack of a tourism master plan, deficient institutional structure, a lack of clear policy for the sector, and problematic transport/infrastructure are just a few of the many problems that are internal to North Cyprus. Both internal and external factors have brought about a culture where by customer value and satisfaction have not been engendered. Customer satisfaction is achieved through the provision of quality product; a quality product is perceived to be in existence when the supplier meets the customers' expectations (Whitfield, 2005a). Due to these external and internal factors the tourism sector of North Cyprus has been unable to compete with other destinations in the region despite its potential to produce a unique product.

To compliment vacation tourism in North $\mathrm{Cy}$ prus, casino development was proposed. Although casino development was permitted in North Cyprus from 1975, it was not until the mid-1990s that the pace of casino development grew. The principle driver for this being the closure of Turkish casinos by the Islamic-led government, which occurred in 1998 (Katircioglu, Arasli, \& Ekiz, 2007; Scott, 2003). It was envisaged that casinos would provide extra leisure opportunities for vacation tourism in North Cyprus (Zaman, 2007), while increasing the demand for hotel accommodation. This includes non-casino hotels being utilized as overflow accommodation for casino hotels, and that casinos would be a source for local employment. Other tourism-related services such as food and beverage outlets and entertainment would also benefit (Benar \& Jenkins, 2008). Additionally, revenue from gaming licenses and taxes would provide a profitable source of income for the government (Scott, 2003). However, in reality the hotels of North Cyprus only achieved full capacity when flights brought mainland visitors from 
Istanbul at Turkish Bayrams (religious holidays) (Warner, 1999). Gambling-related bookings only rose by $10-15 \%$ in the 8 months after the closure of the casinos in Turkey (Tezgör, 1998). Moreover, Turkish visitors stayed for short periods, on average 2.9 days in 2008, with the majority of tourists arriving on inclusive packages. Accommodation and food costs were paid before their arrival (Warner, 1999), resulting in reduced financial expenditure by gaming tourists in the local community, and non-casino hotels remained unfilled (Zaman, 2007). Therefore, casinos tourism has not contributed to the economy as much as anticipated.

Since the border between the North and South opened in April 2003, Greek Cypriots have been viewed as a market for casino tourism in North Cyprus; however, reliance on the Greek Cypriot community may have been overemphasized. A stigma is still attached to Greek Cypriots spending money in the North, which they consider illegitimate and an unrecognized state (Webster \& Dallen, 2006). Furthermore, South Cyprus has itself considered entering the casino industry (Tolgay, 2007), although there is no fundamental shift in motion to achieve this. Although the opening of the border provides an opportunity for the growth of casino tourism, South Cyprus entering the industry poses a significant threat. Consequently, North Cyprus has begun diversifying with investment in conference tourism (TRNC Ministry of Tourism, Environment, and Culture, 2008).

\section{The Conference Sector of North Cyprus}

Destination managers can regenerate a destination by looking at new markets; however, they should seek to protect the destination's traditional markets (Cooper, Fletcher, Gilbert, \& Wanhill, 1998). As such, destinations should identify new markets that are both geographically and behaviorally segmented, thus reducing their dependence on a single market. In order to identify and attract these new markets, changes will be required in the marketing mix. For example, the product offered, in terms of accommodation, attractions, and prices charged, may not meet the needs of the new market and new distribution channels may be required
(Morgan, 1994). In doing so the creation of a conference center also acts as a tool to regenerate the destination's urban image. Furthermore, the overall economic development that is stimulated by conference activity will lead to greater income levels for and higher demands from the host population. This will not only increase taxation revenue available for local investment, but also make local investments more attractive by generating higher levels of local demand for general consumption, particularly for consumer durables (Whitfield, 2005b). This is seen as a cascading effect of expenditure (Rogers, 2003). It is therefore important to create and implement a sustainable strategic tourism plan, designed to protect a destination's traditional markets, while testing markets in selected emergent sectors (Whitfield, 2006).

Although North Cyprus relied on casino tourism, hotel occupancy rates were relatively low, particularly in the winter season (Turkay, 2007). Conference tourism is considered to increase the longevity of the tourism season. Thus, conference tourism is considered to offer opportunities for hotels in North Cyprus. The principle market for conference tourism has been from Turkey. Journey times are less than 1 hour from most Turkish cities. Though Turkey is able to offer a similar, if not more developed, tourism product than North Cyprus, there is still a substantial demand for hosting conferences in North Cyprus. Table 1 shows the frequency of travel of Turkish nationals with respect to place and purpose of travel.

The total number of travelers for conference tourism throughout 2008 was 20,197. Although conference tourism is embryonic, these figures show that the potential growth of conference tourism should not be underestimated. Unlike vacation tourism, whereby factors combine to prevent customer value and satisfaction from being created, the success of the conference sector in North Cyprus will depend on superior customer value and satisfaction being engendered. It is therefore imperative that the government of North Cyprus continually attempt to recognize those product and/ or service attributes deemed critical to generating customer satisfaction as well as customer loyalty in order to maintain a competitive advantage (Deng, 2008). 
Table 1

Frequency of Travel of Turkish Nationals With Respect to Place and Purpose of Travel in 2008

\begin{tabular}{|c|c|c|c|c|c|c|c|c|}
\hline & \multicolumn{2}{|c|}{ First Quarter } & \multicolumn{2}{|c|}{ Second Quarter } & \multicolumn{2}{|c|}{ Third Quarter } & \multicolumn{2}{|c|}{ Fourth Quarter } \\
\hline & TRNC & Other & TRNC & Other & TRNC & Other & TRNC & Other \\
\hline Leisure/ente & & 276,985 & & & & & & 263,493 \\
\hline Visiting relatives & 41,015 & 259,940 & 53,663 & 426,806 & 35,887 & 337,161 & 53,102 & 338,777 \\
\hline Conference & 3,196 & 36,754 & 8,736 & 54,407 & 2,215 & 23,482 & $\mathbf{6 , 0 5 0}$ & 57,807 \\
\hline Duty & 1,065 & 85,759 & 21,216 & 131,037 & 27,912 & 103,674 & 18,821 & 131,074 \\
\hline Trade & 7,457 & 250,352 & 7,488 & 245,8 & 6,646 & 111,649 & 10,755 & 310,545 \\
\hline Education & 1,598 & 28,231 & 6,864 & 56,783 & 6,646 & 49,179 & 7,394 & 47,724 \\
\hline
\end{tabular}

Source: Adapted from Turkiye Istatistik Kurumu (2008).

\section{Methodology}

The empirical data utilized within this study was collected via a quantitative approach using a sample of 250 conference organizers from Turkey. A questionnaire was developed and a list of 25 destination attributes ranging from the destination's conference facilities to the destination's general environment was utilized. Once the questions were devised they were sent to a professional translator for translation into the Turkish language. Although it was anticipated that English is a widely spoken language, to reduce the risk of a low response rate the survey was distributed in Turkish. The questionnaires were emailed to the conference organizers. The surveys were sent out with a cover letter in the body of the email. The data collection period lasted approximately 2 months (August-September 2009) during which three reminder emails were sent out consecutively a week apart from each other. A total response rate of $16.4 \%$ (41 responses) was achieved by the end of the primary data collection period. Primary research was analyzed using a two-step process. The first step included calculating the means and median values of the importance and performance factors. This was achieved through SPSS v17 (Statistical Package for the Social Sciences). Secondly, Importance-Performance Analysis (IPA) was utilized as the main analysis tool to identify the exact strengths and weaknesses of North Cyprus as a conference destination. It also provides policy makers with beneficial insight for recognizing areas of performance that are of main concern and require improvement (Baloglu \& Love, 2003;
Choi \& Boger, 2000; Oppermann, 1996; Weber, 2000).

\section{Importance-Performance Analysis}

IPA, first introduced by Martilla and James (1977), is a framework for analyzing product attributes in order to identify critical performance attributes for products and/or services. The fundamental premise of this technique is to consider the relationship between importance and performance, whereby performance levels for attributes of a particular product/service should be proportional to the importance of the selected attributes (Slack, 1991). The higher the importance rating, the more likely the attribute is to play a critical role in determining customer satisfaction, and conversely the lower the importance ratings the lesser the attributes role in affecting overall perceptions (Barsky, 1995). The objective is to identify those attributes, or combinations of, that are more influential in determining repeat visitation and those that have less impact. This information is invaluable in the process of devising successful marketing strategies (Ford, Joseph, \& Joseph, 1993), and thus "direct scarce resources to areas where performance improvement is likely to have the most effect on overall customer satisfaction" (Lovelock, Patterson, \& Walker, 2001, p. 150),

Fundamental to the success of IPA is the identification of relevant attributes to the situation under investigated. Such attributes can be identified through a literature trawl, focus group interviews as well as managerial judgment. A list of macroand microdestination attributes was established; of 
the 25 attributes, 8 were macrodestination attributes (i.e., they related to North Cyprus in its entirety). A further 17 were microdestination attributes (i.e., they related to individual agents within North Cyprus such as conference venues, accommodation providers, and restaurants). Based on this list of attributes respondents are asked two questions. The first question asks respondents, in relation to North Cyprus, to assign a level of importance to each attribute using a 5-point Likert scale (ranging from "not very important" to "very important"). Following this, respondents were asked to evaluate the performance of North Cyprus with respect to the same list of 25 attributes using a 5-point Likert scale with answers ranging from "very poor" to "excellent." IPA for conference destination selection can be expressed as:

$$
\mathrm{CDA}_{d}={ }_{a=1} \Sigma^{N}\left(1_{a}\right)\left(\mathrm{P}_{a d}\right)
$$

where $\mathrm{CDA}_{d}=$ conference destination attractiveness of destination $d ; \mathrm{I}_{a}=$ importance of attribute $a(a=1, \ldots, N) ; \mathrm{P}_{a d}=$ performance of destination $\mathrm{d}$ with respect to attribute $a$ (Oppermann, 1996, p. 179).

The calculated mean and median performance and importance scores are subsequently used as coordinates for plotting individual attributes on a two-dimensional matrix (Sampson \& Showalter, 1999). Attribute importance is plotted on the $x$ axis and attribute performance on the $y$-axis. The priority for improving attributes are then inferred (Bacon, 2003). From the resultant four-quadrant matrix, as shown in Figure 2, those attributes in quadrant 3 should be viewed as major weaknesses, and thus resources devoted to their immediate improvement (Martilla \& James, 1977). While attributes in quadrant 1 , deemed major strengths should be sustained and promoted (Lambert \& Sharma, 1990). IPA has been employed and extended, including in destination image/selection research (Chon \& Evans, 1989; Chon, Weaver, \& Kim, 1991; Crompton \& Duray, 1985; Go \& Zhang, 1997; Goodrich, 1978; Kanu, Seraku, Takahashi, \& Tsuji, 1984; Sampson \& Showalter, 1999; Weber, 2000; Wu, Hsiao, \& Kuo, 2004). However, the basic framework of IPA remains the same, and it is this basic framework that is utilized within this article.

\section{Findings}

Respondents were asked one prequalifying question concerning the number of conferences they had previously organized in North Cyprus. Results identify that $34.1 \%$ of the sample reported that they had not organized any conference in North Cyprus. Conversely, $31.7 \%$ reported they had organized two or three, $7.4 \%$ reported they had organized four or five, and $26.8 \%$ reported they had organized more than five conferences in North Cyprus. In summary, almost two thirds $(65.9 \%)$ of respondents had organized more than one conference in North Cyprus, and as such were aware of conference facilities within the region.

\section{Importance-Performance Values for Destination Attributes for North Cyprus}

Results show that those factors most important to Turkish conference organizers are related mainly to conference facilities. Conversely, the least important factors are related to leisure activities. The mean values for each of the attributes were calculated to identify the perceived importance level, as shown in Table 2. As indicated in Table 2, 20 attributes had a mean above 4.0, two had means between 3.5 and 4.0, and three had means below 3.0. The attribute with the highest importance mean was ease of accessibility to destination (4.73), followed by availability of high-quality conference venues (4.68), safety and security of destination (4.66), availability of technological resources (4.63), availability of a range of conference venues (4.59), reasonably priced conference venues (4.59), and quantity of good quality hotels (4.54). All these attributes received a median score of 5 . The three least important attributes each with an importance mean below 3.0 were the availability of casinos (2.10), followed by beaches (2.80) and quality of nightlife (2.88). These factors received median scores of 2, 3, and 3 respectively.

Results in Table 2 also show that the mean and median values for performance with regards to the selected North Cyprus attributes were highest for factors relating to the conference destination's environment. Conversely, attributes with a low mean value and thus in need of improvement are related to the destination's conference facilities. The highest performing attribute with a mean above 4.0 
Table 2

Mean and Median Values for Importance and Performance Regarding North Cyprus's Destination Attributes

\begin{tabular}{|c|c|c|c|c|c|c|c|c|}
\hline & $\begin{array}{c}\text { Importance } \\
\text { Mean }\end{array}$ & Rank & $\begin{array}{c}\text { Importance } \\
\text { Median }\end{array}$ & Rank & $\begin{array}{l}\text { Performance } \\
\text { Mean }\end{array}$ & Rank & $\begin{array}{l}\text { Performance } \\
\text { Median }\end{array}$ & Rank \\
\hline Ease of accessibility to destination & 4.73 & 1 & 5.00 & $1=$ & 3.22 & 13 & 3.00 & $2=$ \\
\hline Distance of destination & 4.17 & 15 & 4.00 & $2=$ & 3.56 & 5 & 4.00 & $1=$ \\
\hline Ease of transportation within destination & 4.50 & 7 & 5.00 & $1=$ & 2.98 & 22 & 3.00 & $2=$ \\
\hline Availability of technological resources & 4.63 & 4 & 5.00 & $1=$ & 3.08 & 20 & 3.00 & $2=$ \\
\hline Availability of a range of conference venues & 4.59 & 5 & 5.00 & $1=$ & 3.10 & 19 & 3.00 & $2=$ \\
\hline Reasonably priced conference venues & 4.59 & 5 & 5.00 & $1=$ & 3.28 & 11 & 3.00 & $2=$ \\
\hline Availability of high-quality conference venues & 4.68 & 2 & 5.00 & $1=$ & 2.92 & 23 & 3.00 & $2=$ \\
\hline Availability of trained conference staff & 4.43 & 9 & 5.00 & $1=$ & 2.63 & 25 & 3.00 & $2=$ \\
\hline Availability of congress/exhibition space & 4.49 & 8 & 5.00 & $1=$ & 3.11 & 18 & 3.00 & $2=$ \\
\hline Overall value of organizing a congress & 4.18 & 14 & 4.00 & $2=$ & 3.16 & 15 & 3.00 & $2=$ \\
\hline Availability of casinos & 2.10 & 22 & 2.00 & $4=$ & 3.91 & 2 & 4.00 & $1=$ \\
\hline Quality of nightlife & 2.88 & 20 & 3.00 & $3=$ & 3.24 & 12 & 3.00 & $2=$ \\
\hline Beaches & 2.80 & 21 & 3.00 & $3=$ & 3.62 & 4 & 3.00 & $2=$ \\
\hline City's reputation & 3.85 & 19 & 4.00 & $2=$ & 3.33 & 10 & 3.00 & $2=$ \\
\hline Safety and security of destination & 4.66 & 3 & 5.00 & $1=$ & 3.67 & 3 & 4.00 & $1=$ \\
\hline Climate & 4.07 & 18 & 4.00 & $2=$ & 4.08 & 1 & 4.00 & $1=$ \\
\hline Hospitality & 4.20 & 13 & 4.00 & $2=$ & 3.43 & 6 & 3.00 & $2=$ \\
\hline Local support & 4.30 & 11 & 4.00 & $2=$ & 3.18 & 14 & 3.00 & $2=$ \\
\hline Destinations previous performance & 4.31 & 10 & 4.00 & $2=$ & 3.14 & 16 & 3.00 & $2=$ \\
\hline Promotional appeal & 4.10 & 17 & 4.00 & $2=$ & 3.00 & 21 & 3.00 & $2=$ \\
\hline Destinations marketing activities & 4.11 & 16 & 4.00 & $2=$ & 2.89 & 24 & 3.00 & $2=$ \\
\hline Quality of local restaurants & 4.27 & 12 & 4.00 & $2=$ & 3.13 & 17 & 3.00 & $2=$ \\
\hline Reasonably priced hotel rooms & 4.43 & 9 & 4.00 & $2=$ & 3.34 & 9 & 3.00 & $2=$ \\
\hline Availability of hotel rooms & 4.43 & 9 & 4.00 & $2=$ & 3.35 & 8 & 3.00 & $2=$ \\
\hline Quantity of good quality hotels & 4.54 & 6 & 5.00 & $1=$ & 3.38 & 7 & 3.00 & $2=$ \\
\hline
\end{tabular}

was climate (4.08), followed by availability of casinos (3.91), safety and security of destination (3.67), beaches (3.62), distance of destination (3.56), hospitality (3.43), and quantity of good quality hotels (3.38). The remaining attributes were all above 2.5 with the three lowest attributes being availability of trained conference staff (2.63), destination's marketing activities (2.89), and availability of high-quality conference venues (2.92). Median scores for all attributes regarding performance were either 4 or 3 . Overall, those attributes with the highest performance were associated with the destination's general environment; alternatively, those attributes with low performance levels were the destination's conference facilities.

\section{Importance-Performance Analysis of North Cyprus as a Conference Destination}

IPA was then undertaken for the destination attributes, utilizing these mean and median ranking values. Figure 1 shows IPA undertaken using the mean values, while Figure 2 shows IPA using median values.
For Figure 1 the overall mean for importance (3.0) and the overall mean for performance (3.15) were used to divide the plot into four quadrants, while the median value of 3 was used to divide Figure 2 into the respective quadrants. The four quadrants distinguish between low and high importance and between low and high performance. Quadrant 1 on Figures 1 and 2 is classified as "Keep up the good work," and attributes in this quadrant represent attributes considered important to the sample and also having a high score for performance.

It can be identified that 12 attributes fall within this quadrant based on the mean values, while this reduces to 3 if the median is used. Overall, results show that it is North Cyprus as a conference destination that is the region's strengths, followed by the accommodation offered and to a lesser extent the conference venues when mean scores are examined. Overall, a higher proportion of macrodestination attributes feature in this quadrant. The following destination-related attributes received high importance and performance mean 


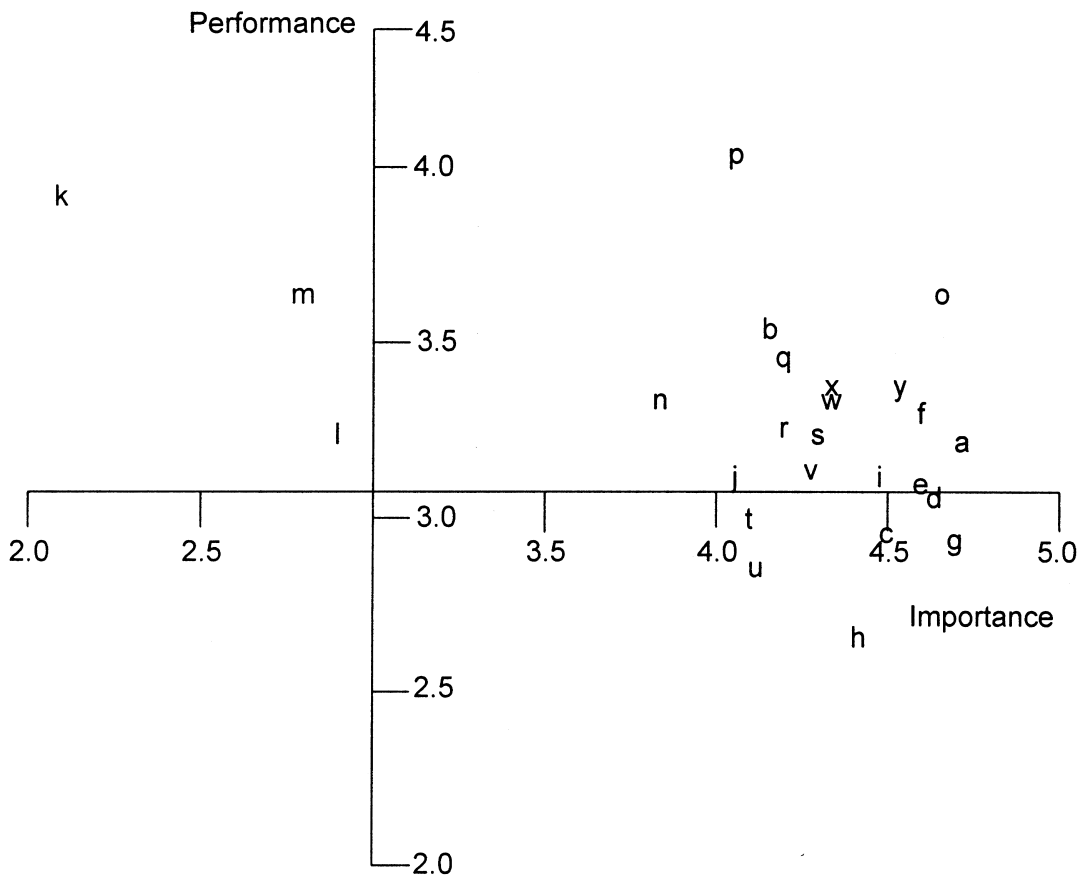

\begin{tabular}{|ll|}
\hline id Factor & id Factor \\
a Ease of accessibility to destination & n City's reputation \\
b Distance of destination & o Safety and security of destination \\
c Ease of transportation within destination & p Climate \\
d Availability of technological resources & q Hospitality \\
e Availability of a range of conference venues & r Local support \\
f Reasonably priced conference venues & s Destination's previous performance \\
g Availability of high-quality conference venues & t Promotional appeal \\
h Availability of trained conference staff & u Destination's marketing activities \\
i Availability of congress/exhibition space & v Quality of local restaurants \\
j Overall value of organizing a congress & w Reasonably priced hotel rooms \\
k Availability of casinos & x Availability of hotel rooms \\
l Quality of nightlife & y Quantity of good quality hotels \\
m Beaches & \\
\hline
\end{tabular}

Figure 1. Importance performance graph for North Cyprus attributes (mean values).

scores: ease of accessibility, distance of destination, city's reputation, safety and security of destination, climate, hospitality, local support. The following accommodation-related attributes also received high importance and performance mean scores: reasonably priced hotel rooms, availability of hotel rooms, and quantity of good quality hotels. Finally, two venue-related attributes are in this quadrant: reasonably priced conference ven- ues and overall value of organizing a congress. The three attributes in this quadrant, by virtue of their median scores, are a subset of those listed, and are drawn from the destination-related attributes identified; these being are distance of destination, safety and security of destination, and climate.

Quadrant 2 ("Possible overkill") represents attributes with a low importance but high perfor- 
mance score. Based on the mean values, three attributes are identified: availability of casinos, beaches, and quality of nightlife in North Cyprus all have higher performance scores than what the sample perceived important for a conference destination. Again, as with quadrant 1, utilizing the median values creates a smaller subset of these attributes; indeed, only one attribute, that of availability of casinos, is located in this quadrant based on median values. The attributes that feature in this quadrant, either using mean or median values, are all microdestination attributes.

Quadrant 3 entitled "Low priority" is comprised of those attributes low in both importance and performance. Based on the mean values, IPA has not identified any destination attribute that is low in both importance and performance for North Cyprus. However, undertaking IPA using median

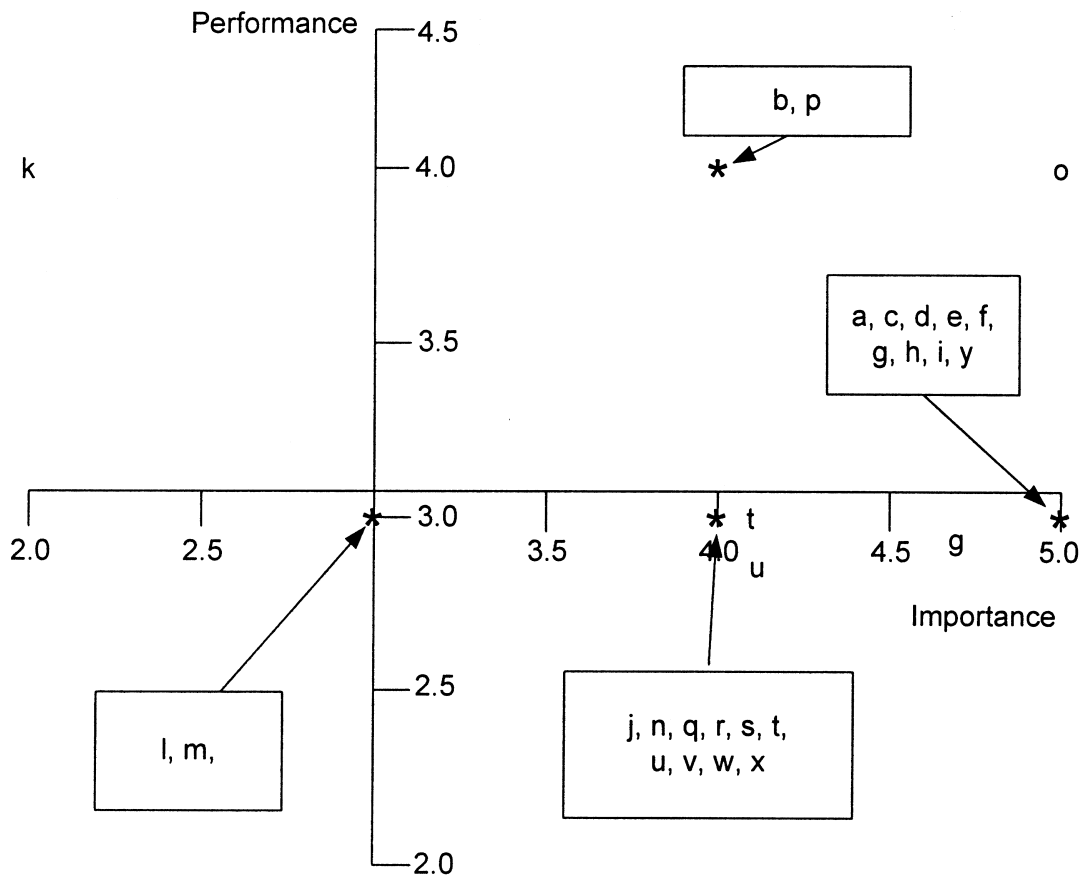

\begin{tabular}{|ll|}
\hline id Factor & id Factor \\
a Ease of accessibility to destination & $\mathrm{n}$. City's reputation \\
$\mathrm{b}$ Distance of destination & $\mathrm{o}$ Safety and security of destination \\
$\mathrm{c}$ Ease of transportation within destination & $\mathrm{p}$ Climate \\
$\mathrm{d}$ Availability of technological resources & $\mathrm{q}$ Hospitality \\
e Availability of a range of conference venues & $\mathrm{r}$ Local support \\
$\mathrm{f}$ Reasonably priced conference venues & $\mathrm{s}$ Destination's previous performance \\
$\mathrm{g}$ Availability of high-quality conference venues & $\mathrm{t}$ Promotional appeal \\
$\mathrm{h}$ Availability of trained conference staff & $\mathrm{u}$ Destination's marketing activities \\
$\mathrm{i}$ Availability of congress/exhibition space & $\mathrm{v}$ Quality of local restaurants \\
$\mathrm{j}$ Overall value of organizing a congress & $\mathrm{w}$ Reasonably priced hotel rooms \\
$\mathrm{k}$ Availability of casinos & $\mathrm{x}$ Availability of hotel rooms \\
l Quality of nightlife & $\mathrm{y}$ Quantity of good quality hotels \\
$\mathrm{m}$ Beaches &
\end{tabular}

Figure 2. Importance performance graph for North Cyprus attributes (median values). 
values places beaches and quality of nightlife in North Cyprus in this quadrant. Again, as with quadrant 2, the attributes that feature in this quadrant, either using mean or median values, are all microdestination attributes.

This quadrant has 10 attributes, based on the mean value, on which the sample considered to be highly important but which North Cyprus performed low in. Of these 10 half are venue specific, these being: availability of a range of conference venues, availability of high-quality conference venues, availability of trained conference staff, availability of congress/exhibition space, and availability of technological resources. A further five are destination related: ease of transportation within destination, destination's previous performance, promotional appeal, destination's marketing activities, and quality of local restaurants. Based on the median values, the same 10 attributes are located in this quadrant along with a further 9 attributes. These are: availability of hotels rooms, city's reputation, ease of accessibility to destination, hospitality, local support, overall value of organizing a congress, quantity of good quality hotels, reasonably priced conference venues, and reasonably priced hotel rooms. Overall, a higher proportion of microdestination attributes feature in this quadrant.

Results identified that there are both similarities and differences between IPA using mean and median values. Where mean values are used, more attributes are located in both quadrants 1 and 2 . However, the use of median values results in a subset of the attributes identified using the mean values. No new attributes are introduced into quadrants 1 and 2 . The converse is true for quadrants 3 and 4 . In these quadrants more attributes are identified by utilizing the median than by the mean value. Indeed, two factors identified in quadrant 2 using the mean appear in quadrant 4 when using the median, a shift from "Possibly overkill" to "Low priority." A further 9 attributes appear in quadrant 1 when using the mean values, which are subsequently located in quadrant 4 when the median values are utilized, thus a more significant move from "Keep up the good work" to "Concentrate here."

\section{Conclusions}

Due to the political, economic, and sociocultural turmoil witnessed within Cyprus over the last three decades, and with trade embargoes applied to North Cyprus, it has been virtually impossible for mass tourism to serve as a sustainable industry. North Cyprus benefitted from the closure of casinos in Turkey in 1998 given its close proximity to Turkey. Although this sector proved to be attractive initially, it meant North Cyprus was heavily reliant on Turkey. This accounted for a lack of foreign currency into the island as well as short average lengths of stay, economic, and social impacts on the island. These issues and the threat of South Cyprus entering the casino industry instigated a search for alternative forms of tourism in North Cyprus. However, $34.1 \%$ of respondents reported that they had not organized any conferences in North Cyprus yet. This is in line with findings from the literature review, which state that the conference sector is a newly developing sector in North Cyprus. In line with this, North Cyprus has begun promoting itself as a conference destination. With heavy investments and continuing developments in the conference industry, North Cyprus has created a further reason to attract Turkish nationals to the island.

Research suggests that there are particular attributes that significantly influence and determine whether a conference organizer will choose a conference destination. These attributes are assigned a degree of importance on behalf of the industry stakeholders. A destination whose attributes are in balance with conference organizers expectations is more likely to be in included in the conference destination selection process. Thus, understanding the opinions of conference organizers may provide useful content for not only the destination's marketing and promotional messages, but also for microdestination agents.

Empirical results show those factors most important to conference organizers are related mainly to conference facilities, these being: the ease of accessibility to destination, followed by availability of high-quality conference venues, safety and security of destination, availability of technological resources, availability of a range of conference 
venues, reasonably priced conference venues, and quantity of good quality hotels. Conversely, the least important factors are related to leisure activities, these being: the availability of casinos, followed by beaches, and quality of nightlife. The assessment of North Cyprus's performance with respect to the same attributes demonstrated that North Cyprus performed the highest in factors related mainly to the conference destinations environment. Conversely, areas that need improvement in North Cyprus are more controllable attributes and the destinations conference facilities. The results demonstrated that North Cyprus seemingly performed best in climate, availability of casinos, and safety and security of destination. Despite this, North Cyprus apparently did not meet expectations in the attributes availability of trained conference staff, destinations marketing activities, and availability of high-quality conference venues. These responses provide useful insights towards the respondents' perceptions of attributes considered important in conference destination selection and the performance of North Cyprus in relation to these attributes. However, these results alone are not in the position to clearly describe where North Cyprus stands in terms of meeting expectations of the industry stakeholders at hand.

An IPA was also conducted using the mean and median values, and showed that North Cyprus performed well, based on mean values, in highly important areas to conference organizers such as ease of accessibility, distance of destination, reasonably priced conference venues, overall value of organizing a congress, city's reputation, safety and security of destination, climate, hospitality, local support, reasonably priced hotel rooms, availability of hotel rooms, and quantity of good quality hotels. Indeed, distance of destination, safety and security of destination, and climate were also identified via the median values. Availability of casinos, beaches, and quality of nightlife in North Cyprus are either considered as possible overkill or are of a low priority in the decision-making process. However, North Cyprus was seemingly perceived a relatively low performer in other highly important areas; for instance, ease of transportation within destination, availability of technologi- cal resources, availability of a range of conference venues, availability of high-quality conference venues, availability of trained conference staff, availability of congress/exhibition space, destination's previous performance, promotional appeal, destination's marketing activities, and quality of local restaurants. Most of these attributes happened to be related to the destination's conference facilities.

\section{Discussion}

The majority of respondents placed a high degree of importance on ease of accessibility to the destination, availability of high-quality conference venues, safety and security of destination, availability of technological resources, availability of a range of conference venues, reasonably priced conference venues, and quantity of good quality hotels. Findings of this study support research results from conference destination selection studies conducted by numerous researchers (Baloglu \& Love, 2003; Crouch \& Ritchie, 1998; Kim \& Kim, 2005; Lee \& Back, 2005; Oppermann, 1996). They too found that the destination's conference facilities, accessibility, the destinations environment, and cost were the most significant factors contributing to conference destination selection. Regarding performance, the literature review describes that North Cyprus is insufficient in public transport and has a lack of infrastructure. This is congruent with the findings of the primary research related to the low performance of ease of transport, the availability of a range of conference venues, and the availability of high-quality conference venues. Additionally, the nonrecognition of North Cyprus (Warner, 1999) and the lack of marketing in the past (L. Altinay, Altinay, \& Bicak, 2002) justify conference organizers' perceived low performance of North Cyprus's promotional appeal and marketing activities.

There is one aspect of the primary research that was incongruent with the literature review. The TRNC Ministry of Tourism, Environment, and Culture (2008) believe the safety and security of North Cyprus is a weakness; however, the sample perceives North Cyprus to be a high performer in this attribute. This factor could be one of the principle macrodestination attributes that may be used 
to develop a "Conference Cyprus" branding. Branding should focus on the strengths of North Cyprus and hence other macrodestination attributes of distance from mainland Europe, along with the climate should be central to any branding/advertising campaign. Microdestination attributes should also be incorporated; these include the pricing of both conference venues and accommodation, along with the quantity and availability of accommodation. Although mention may be made of beaches and nightlife that North Cyprus has to offer conference delegates, these should be marginalized in any promotion of North Cyprus's conference sector. Indeed, destination managers as well as managers of microdestination agencies of any postconflict areas can learn lessons from this research. By identifying and promoting those attributes that fall into the category of "Keep up the good work," marginalizing those that are deemed "Possible overkill" or "Low priority," while selecting favorable attributes from those viewed as "Concentrate here," postconflict regions can begin to build a brand that can be promoted.

It should be noted that several attributes in the "Concentrate here" quadrant are elementary in creating a successful conference-a principle attribute being "Ease of transportation within the destination." While the branding and promotion of "Conference Cyprus" is essential, it is fundamental to its continued success that sufficient infrastructure is put in place, not just in terms of tarmac, but also in terms of the availability of congress, exhibition, and high-quality conference venues as well as technological resources and trained conference staff. Doing this should ensure that North Cyprus is not putting the metaphorical "conference cart before the horse."

\section{Recommendations for the North Cyprus Conference Industry}

This research study makes the following recommendations for the North Cyprus conference sector.

- North Cyprus performed poorly with regards to transportation even though it is ranked highly important in conference destination selection. The government in North Cyprus should im- prove both public transport systems and the North's transport infrastructure.

- North Cyprus needs to continue making further investments towards conference venues with larger meeting space and high-quality technological resources.

- The performance of conference staff in North Cyprus was poor. Universities in North Cyprus do not offer education in conferences and exhibitions. Academic and vocational institutes that offer education towards tourism should incorporate congress/convention courses in their curriculum.

- Policy makers and tourism officials should conduct regular studies to assess the performance of the conference industry in North Cyprus. The findings should identify North Cyprus's position in the conference market and help recognize the strengths and weaknesses of particular attributes.

- The quality of local restaurants must be increased. It is recommended that tourism establishments organize in-house training sessions on service quality. In addition to this, external quality inspections should commence regularly.

As for those attributes considered important by the sample and that performed well ("Keep up the good work"), it is advised that the destination emphasizes these factors during marketing and promotional activities in order to target industry stakeholders. Furthermore, although there was a few attributes falling into the "Possible overkill" quadrant it does not represent that resources should be cut because attributes are performing higher than necessary. In fact, in the current competitive environment, it may be these attributes that help differentiate North Cyprus against other destinations with similar attributes during the conference destination selection process, because they account for additional leisure activities contributing to the overall tourism product.

\section{References}

Akis, S., Peristianis, N., \& Warner, J. (1996). Residents attitudes to tourism development: The case of Cyprus. Tourism Management, 17(7), 481-494.

Alipour, H., \& Kilic, H. (2005). An institutional appraisal of tourism development and planning: The case of the 
Turkish Republic of North Cyprus (TRNC). Tourism Management, 26(1), 79-94.

Altinay, L., Altinay, M., \& Bicak, H. (2002). Political scenarios: The future of the North Cyprus tourism industry. International Journal of Contemporary Hospitality Management, 14(4), 176-182.

Altinay, M., \& Bicak, H. A. (1998). Competitive strategies for the tourism sector of a small island state: The case of North Cyprus. Journal of Vacation Marketing, 4(2), 136.

Altinay, M., \& Hussain, K. (2005). Sustainable tourism development: A case study of North Cyprus. International Journal of Contemporary Hospitality Management, 17(3), 272-280.

Andronikou, A. (1987). Development of tourism in Cyprus: Harmonization of tourism with the environment. $\mathrm{Ni}$ cosia: Cosmos.

Arasli, H., Katircioglu, S., \& Mehtap-Smadi, S. (2005) Customer service quality in the Greek Cypriot banking industry. Managing Service Quality, 15(1), 41-56.

Aron, J. (2000). Growth and institutions: A review of the evidence. World Bank Research Observer, 15(1), 99135.

Bacon, D. R. (2003). A comparison of approaches to importance-performance analysis. International Journal of Market Research, 45(1), 55-71.

Baloglu, S., \& Love, C. (2003). Association meeting planners' perceived performance of Las Vegas: An importance-performance analysis. Journal of Convention \& Exhibition Management, 5(1) 13-27.

Barsky, J. D. (1995). World-class customer satisfaction. Chicago, IL: Irwin Publishing.

Benar, H., \& Jenkins, G. (2008). The economics of casino taxation. Applied Economic, 40(1), 63-73.

Butler, R. W., \& Mao, B. (1995). Tourism between quasistates. In R. W. Butler \& D. Pearce (Eds.), Change in tourism (pp. 92-113). London: Routledge

Choi, J., \& Boger, Jr., C. A. (2000). Association planner's satisfaction: An application of importance-performance analysis. Journal of Convention \& Exhibition Management, 2(3), 113-130.

Chon, K-S., \& Evans, M. R. (1989). Formulating and evaluating tourism policy using importance-performance analysis. Hospitality Education and Research, 13(2), 203-213.

Chon, K-S., Weaver, P. A., \& Kim, C-Y. (1991). Marketing your community: Image analysis in Norfolk. Cornell Hotel and Restaurant Administration Quarterly, 31(3), 31-37.

Clements, M. (1998). Planning to tourism capacity in a crisis. Journal of Travel Research, 37(1), 56-62.

Cooper, C., Fletcher, J., Gilbert, D., Wanhill, S., \& Shepherd, R. (Eds.). (1998). Tourism principles and practice (2nd ed., pp. 116-117). London: Longman.

Crompton, J. L., \& Duray, N. A. (1985). An investigation of the relative efficacy of four alternative approaches to importance performance analysis. Journal Academy of Marketing Science, 3(4), 69-80.
Crouch, G. I., \& Ritchie, J. R. B. (1998). Convention site selection research: A review, conceptual model, and prepositional framework. Journal of Convention \& Exhibition Management, 1(1), 49-69.

Deng, W. (2008). Fuzzy importance-performance analysis for determining critical service attributes. International Journal of Service Industry Management, 19(2), 252270.

Dodd, C. H. (1995). The Cyprus issue: A current perspective. Cambridgeshire: The Eothen Press.

Ford, J. W., Joseph, M., \& Joseph, B. (1993). Service quality in higher education: A comparison of universities in the United States and New Zealand using SERQUAL Unpublished manuscript. Old Dominion University, Norfolk, VA.

Gurbuz, M. F. (2009). Turizm bilinclendirme, yapilandirma ve tanitim stratejileri icin oneriler. Ankara: Serenas Group.

Go, F., \& Zhang, W. (1997). Applying Importance-Performance Analysis to Beijing as an international meeting destination. Journal of Travel Research, 35(4), 42-49.

Goodrich, J. N. (1978). The relationship between preferences for and perceptions of vacation destinations: Application of a choice model. Journal of Travel Research, 17(2), 8-13.

Hawes, J. M., \& Rao, C. P. (1985). Using importanceperformance analysis to develop health care marketing strategies. Journal of Health Care Marketing, 5, 19-25.

Hitchens, C. (1997). Hostage to history: Cyprus from the Ottomans to Kissinger (3rd ed.). New York: Verso Books.

Ioannides, D. (1995). A flawed implementation of sustainable tourism: The experience of Akamas, Cyprus. Tourism Management, 16(8), 583-592 .

Kanu, N., Seraku, N., Takahashi, F., \& Tsuji, S. (1984). Attractive quality and must-be quality. The Journal of Japanese Society for Quality Control, 14, 39-48.

Katircioglu, S. T., Arasli, H., \& Ekiz, E. H. (2007). Trends in tourism in North Cyprus: A historical perspective, $e$ Review of Tourism Research, 5(2). Retrieved April 14, 2009, from http://ertr.tamu.edu/attachments/175_a-5-23.pdf

Kim, H., \& Kim, W. G. (2005). The relationship between $\mathrm{BE}$ and firm's performance in luxury hotels and chain restaurants. Tourism Management, 26(4), 549-60.

Lambert, D. M., \& Sharma, A. (1990). A customer-based competitive analysis for logistics decisions. International Journal of Physical Distribution \& Logistics Management, 20(1), 17-24.

Lee, M., \& Back, K. (2005). A review of convention and meeting management research 1990-2003: Identification of statistical methods and subject areas. Journal of Convention \& Event Tourism, 7(2), 1-20.

Lockhart, D. G. (1997). Tourism to Malta and Cyprus. In D. G. Lockhart \& D. Drakakis-Smith (Eds.), Island tourism (pp. 152-180). London: Pinter.

Lovelock, C., Patterson, P. G., \& Walker, R. H. (2001). 
Services marketing: An Asia-Pacific perspective. Sydney: Prentice-Hall.

Martilla, J. A., \& James, J. C. (1977). Importance-performance analysis. Journal of Marketing, 41(1), 77-79.

Matzler, K., Fuchs, M., \& Schubert, A. K. (2004). Employee satisfaction: Does Kano's model apply? Total Quality Management \& Business Excellence, 15(9/10), 1179-1198.

Morgan, M. (1994). Homogeneous products: The future of established resorts. In W. Theobald (Ed.), Global tourism: The next decade. Oxford: Butterworth Heinemann.

Myers, J. H. (1999). Measuring customer satisfaction: Hot buttons and other measurement issues. Chicago, IL: American Marketing Association.

Oppermann, M. (1996) Convention destination images: Analysis of association meeting planners' perceptions. Tourism Management 17(3), 75-182.

Ostergren, R. C., \& Rice, J. G. (2004). The Europeans: A geography of people, culture, and environment (Texts in Regional Geography). New York: Guilford Press.

Rogers, T. (2003). Conferences and conventions. Harlow: Addison Wesley Longman.

Rustem, K. (1987). North Cyprus almanac. London: Contact Type Setting Systems Ltd.

Sampson, S. E., \& Showalter, M. J. (1999). The performance-importance response function: Observations and implications. The Service in Industries Journal, 19(3), $1-25$.

Scott, J. E. (2003). Coffee Shop meets casino: Cultural responses to casino tourism in Northern Cyprus. Journal of Sustainable Tourism, 11(2/3), 266-279.

Slack, N. (1991). The importance-performance matrix as a determinant of improvement priority. International Journal of Operations \& Production Management, 14(1), $59-75$.

Sonmez, S., \& Apostolopoulos, Y. (2000). Conflict resolution through tourism cooperation? The case of the positioned island-state of Cyprus. Journal of Travel and Tourism Marketing, 9(3), 35-49.

Tezgör, G. (1998, October 4). Reuters news report, Nicosia.

Tolgay, A. (2007). Rumlar kumar darbesine hazırlanıyor. Kıbris Gazetesi.

TRNC Ministry of Tourism, Environment, and Culture. (2008). Turizm gelisim plani. Retrieved June 19, 2009, from http://www.turizmcevrekultur.org/upload/pdf/2008 .05.26_20-22-27Turizm-Master-Plan-23-5-08.pdf

Turkay, S. (2007) Personal correspondence cited in Turizmforumu. (2007). KKTC'nin umudu kongre ve sağlıkta. Turizm Haberleri. Retrieved July 7, 2009, from http:// www.turizmhaberleri.com/Haberayrinti.asp?ID $=5705$

Turkiye Istatistik Kurumu. (2008). Turizm istatistikleri. Turkiye: T.C Basbakanlik. Retrieved August 16, 2009, from www.tuik.gov.tr

Warner, J. (1999). North Cyprus: Tourism and the challenge of nonrecognition. Journal of Sustainable Tourism, 7(2), 128-145.

Weber, K. (2000). Meeting planners perceptions of hotelchain practices and benefits. Cornell Hotel and Restaurant Administration Quarterly, 41(4), 32-38.

Webster, C., \& Dallen, T. J. (2006). Travelling to the "other side": The occupied zone and Greek Cypriot views of crossing the green line. Tourism Geographies, 8(2), $162-181$.

Whitfield, J. E. (2005a). Service quality: Strengths and weaknesses within the four UK conference venue typologies. In The 5th China (Wuhu) International Tourism Commodities Exposition, 2005, Wuhu, China (unpublished).

Whitfield, J. E. (2005b). An analysis and critique of an evolving conference industry within the UK from post war to the present day. Ph.D thesis, Bournemouth University, Dorset, UK.

Whitfield, J. E. (2006). Why build purpose-built conference venues? Forecasting new build. Journal of Retail and Leisure Property, 6(1), 47-60.

Whitfield, J. E. (2009). The cyclical representation of the UK conference sector's lifecycle-the use of refurbishments as rejuvenation triggers. Tourism Analysis, 14(5), $559-572$.

Wu, W. Y., Hsiao, S. W., \& Kuo, H. P. (2004). Fuzzy set theory based decision model for determining market position and developing strategy for hospital service quality. Total Quality Management, 15(4), 439-456.

Yirmibesoglu, G. (2008). Constraints on women politicians in Northern Cyprus. Equal Opportunities International, 27(8), 692-708.

Zaman G. (2007). KKTC, ekonomisini kumarla değil 'gerçek turizm'le büyütecek. Retrieved July 7, 2009, from http://www.porttakal.com/haber-kktc-ekonomisini-kuma rla-degil-gercek-turizm-le-buyutecek-100820.html 